\title{
Study of Prevalence, Clinical Pattern and Outcome of Acute Organophosphate Poisoning Patients Admitted in Al Gamhouria Teaching Hospital and Private Hospital and in Aden City - Yemen
}

\author{
OSAM SAEED ABDO GABALI, M.D. and AHMED SALEH OMAR AL-GEFRI, M.D. \\ The Department of Internal Medicine, Faculty of Medicine and Health Sciences, Aden University, Yemen
}

\begin{abstract}
Background: Organophosphates (OP) are one of the most common agents of poisoning in developing countries including Yemen. Where agriculture is a major component of the economy.

Aim of Study: This study aimed to describe the prevalence, clinical pattern and outcome of patients with organophosphorus poisoning admitting a private hospital and in Al-Ggamhouria Teaching Hospital in Aden city in Yemen.

Patients and Methods: It was a prospective study carried out in Al-Gamhouria Teaching Hospital and Private Hospital in Aden-Yemen over a period of two years, Between August 2019 to August 2021. It included 50 patients $>16$ years of age presented with organophosphates poisoning within 6 hours of OP exposure. Diagnosis was performed from the history taken from the patient, particular focus being given for sex, age, rural/urban background, clinical symptomatology, in addition to outcome.
\end{abstract}

Results: During the study period, 50 patients were recruited, mean age was $32 \pm 10$ years, $(62 \%)$ cases were females and $(38 \%)$ were males, maximum of patients belonging to the age group of $21-40$ years $(70 \%)$, sweating was the most common clinical pattern at time of arrival, it was (92\%) follow by Miosis $(80 \%)$ excessive salivation $(68 \%)$ bradycardia $50 \%$ muscle weakness $(10 \%)$. Dead patients are $(26 \%)$ of the subjects, while $(74 \%)$ of patients were fully recovered.

Conclusion: This study concluded that young female patients are the majority of patients with OP poisoning encountered in hospitals, and sweating is the commonest presentation seen.

Key Words: Organophosphorous compounds - Sweating Excessive salivation.

\section{Introduction}

THIS entity of chemicals was discovered by Schrader during II world war. Organophosphorous compounds (O.P.) are widely used for agriculture,

Correspondence to: Dr. Osam Saeed Abdo Gabali, The Department of Internal Medicine, Faculty of Medicine and Health Sciences, Aden University, Yemen vector control and domestic purpose. In developing countries, these products are easily available and could lead to intentional, accidental and occupational exposure. As per literature, about 3 million exposures occur annually worldwide. As per WHO estimate O.P. poisoning is a cause of more than 2.2 million deaths annually. Countries like Srilanka and India have higher rates of exposure and mortality [1].

Organophosphorous use in Yemen is widespread in rural areas, with farming as a major occupation, especially in Al Dhalea Governorate located in southern part of Yemen, inhibitants of this government planting khat (Catha edulis) which contains the alkaloid cathinone, which has euphoric properties and chewing it as social custom, and use OP compounds as insecticides, it is avaible inside and outside their homes with easily access for all home members, so rising numbers of intoxications by (O.P) compounds from this governorate is extremely noticeable. Unfortunately There are only a few studies published in Yemen points the epidemiological background, clinical patterns of acute O.P poisoning, and its outcome.

Acute poisoning is a medical emergency. It is important to know the nature, severity and outcome of acute poisoning cases in order to take up appropriate planning, prevention and management techniques. Patients exhibit muscarinic and nicotinic symptoms depending upon the severity of compound. Muscarinic symptoms such as nausea, vomiting, diarrhoea, sweating, salivation, urination, stool in continence, lacrimation, miosis and bradycardia and nicotinic signs such as muscular weakness, fasciculation, paralysis, convulsions and coma are found. 
O.P. compounds lead to acute and chronic complications. Acute complications include acute respiratory failure, acute respiratory distress syndrome, type I and II respiratory paralysis, intermediate syndrome, sudden cardiac death, aspiration pneumonia. Chronic complication include anxiety, depression, polyneuropathy paralysis and coma. Poisoning in these cases is often serious and requires treatment in intensive care unit, as they present with life threatening complications and may result in mortality. It may also affect respiration, which may endanger the individual's life [2]

\section{Patients and Methods}

This was a prospective study carried out in a private hospital and in Al-Gamhouria Teaching Hospital in Aden city southwest of Yemen over a period of two years, Between August 2019 to to August 2021, It included 50 patients with either acute unintentional or intentional poisoning, all patients $>16$ years of age presenting to emergency and intensive care units within 6 hours of organophosphate poisoning. Data was collected from patients using a pre-determined questionnaire, particular emphasis being given to, sex, age, rural /urban background, symptoms at time of arrival and outcome.

Poisoned cases are usually diagnosed on the basis of history of exposure or contact and characteristic clinical picture specially presence of sweating, salivation, meiosis, Bradycardia. And muscle weakness. The bottle of consumed OP compound often accompanies the patient to the Emergency Department. If a patient did not present with a clinical history or clinical features consistent with OP poisoning, they were excluded from the study. The result was calculated manually, and presented as means, percentages and tables as appropriate

Ethical consideration: Verbal informed consent was obtained from all participating subjects; the study design was approved by the research and ethics committee in the Faculty of Medicine, University of Ade.

\section{Results}

A total of (50) subjects were included in this study, they were presented within 6 hours of OP ingestion or inhalation, Their age range from 17 to 62 with a mean value $(32 \pm 10) \mathrm{SD}$ years.

The sex distribution in (Table 1) showed a prominence of female gender $(62 \%)$ versus $(38 \%)$ being male. All patients came from Al Dhalea Governorate.
Table (2) showed maximum of patients belonging to the age group of 21-40 years (70\%).

Table (3) demonstrated the Clinical Manifestation of organophosphorus poisoning and showed sweating was the most common manifestation at time of arrival, it was (92\%) follow by Miosis $(80 \%)$ excessive salivation $(68 \%)$ bradycardia $(50 \%)$ muscle weakness $(10 \%)$.

More than one clinical manifestation was presented in one patient.

Table (4) revealed the final outcome of subjects enrolled in this study (26\%) of the subjects dead, while $(74 \%)$ of patients were fully recovered.

Table (1): Distribution of patients according sex.

\begin{tabular}{lc}
\hline Sex & Number $(\%)$ \\
\hline Female & $31(62 \%)$ \\
Male & $19(38 \%)$ \\
\hline
\end{tabular}

Table (2): Distribution of patients according age.

\begin{tabular}{cc}
\hline Age group & Number $(\%)$ \\
\hline$<20$ & $2(4 \%)$ \\
$21-40$ & $35(70 \%)$ \\
$41-60$ & $11(22 \%)$ \\
$>60$ & $2(4 \%)$ \\
\hline
\end{tabular}

Table (3): Clinical Manifestation of organ phosphorus poisoning at time of arrival.

\begin{tabular}{ll}
\hline $\begin{array}{c}\text { Clinical pattern of } \\
\text { organophosphorus } \\
\text { poisoning at time of arrival }\end{array}$ & Number $(\%)$ \\
\hline Sweating & $46(92 \%)$ \\
Miosis & $40(80 \%)$ \\
Salivation & $34(68 \%)$ \\
Bradycardia & $25(50 \%)$ \\
Muscle weakness & $5(10 \%)$ \\
\hline
\end{tabular}

Table (4): Distribution of patients according outcome.

\begin{tabular}{lc}
\hline Outcome & Number (\%) \\
\hline Fully recovered & $37(74)$ \\
Dead & $13(26)$ \\
\hline
\end{tabular}

\section{Discussion}

Organophosphates poisoning (OP) is a major health problem all over the world, particularly in the developing countries due to widespread usage and application of pesticides in agricultural and environmental pest control [3]. 
Easy availability and excessive popularity of its use as insecticides and pesticides has increased the incidence of ingestion, resulting in increasing suicidal and unintentional poisoning [4] .

A total of 50 subjects were included in this study, all patients came from $\mathrm{Al}$ dhalea governorate it is a governorate famous with rising qat, The majority of subjects were female $(62 \%)$. This preponderance of female over males may be due to increased incidence of suicide in females being more sensitive and can be affected easily by emotional conflicts, and females sharing males in spraying insecticide in their farms in Yemeni countryside, the result was in agreement with Adinew et al., study conducted in University of Gondar Teaching Hospital, Northwest Ethiopia where Out of the 90 cases studied 60\% (54) were female, [5] also two studies in Nepal made by Chataut et al., [6] and Banerjee et al., [7] where female constitutes $58 \%$ of included patients, This study result was not in agreement with the findings of D.M. Amin et al., [8] study conducted in Zagazig University Hospital, in Egypt where $60.53 \%$ was male $39.47 \%$ was female among 76 study subjects.

The majority of patients were related to the age group of 21-40 years (70\%) Approximately near the result mentioned by Selvaraj et al., [9] in his study carried out in Tamilnadu in India where $67 \%$ of poisoning cases where in the age group 21-40 years, The mean age was $32 \pm 10$ years close to the The mean age of the patients in Kumar et al., [10] study which published World Journal of Pharmacy and Pharmaceutical Sciences which was $31.73 \pm 10.90$.

Among patients enrolled in this study, sweating was the most encountered manifestation, it was $(92 \%)$ in agreement with the result obtained by Ojha UK et al., [11] which was $98 \%$ and higher than figure mentioned by Gagarin in his study which sweating constitute $60 \%$ of symptoms.

This study reported that excessive salivation constitutes $(68 \%)$ close to the result mentioned by Chintale et al., [12] Which reported that excessive salivation was the most common symptom observed $(72.05 \%)$.

Higher than the the result made by Jumaan, et al., [13] study carried out in King Fahd Hospital in the Kingdom of Saudi Arabia Where 11 cases from total of 50 subjects recruited (22\%) had excessive salivation.

This study reported that Miosis was (80\%) among enrolled subjects, it was in agreement with Noshad et al., [14] observation, which was (82\%).
Our study reported that muscle weakness was (10\%) close to Divekar S et al., [15] study where weakness was $(7.9 \%)$.

Bradycardia constitutes (50\%) in our study, comparable to results conducted by Chintale et al., [12] where bradycardia was $(57.35 \%)$.

Mortality rate in our study was $26 \%$, which agreed to results reported by GV Rao et al., [16] .

Where mortality rate of $(27 \%)$ was observed and close with result made by Gagarin P.Y. et al., [17] study conducted in India where dead cases constitute $25 \%$ of the subjects.

And higher than result obtained by D.M. Amin et al., [8] (11.53\%) of the 76 patients died.

Shah et al., [18] in their study observed complete recovery and mortality rate as $66.47 \%$ and $16.47 \%$ among cases respectively.

Recommendations: Lack of rules and regulations for the sale of pesticides resulted in wide spread use of Organophosphate as one of the most common poison used for deliberate self-harm.

This data suggests that it is essential to strengthen Yemeni regulatory policy concerning the availability of OPCs. Additionally, it will be important to design an appropriate health education program for the prevention of both suicidal and accidental OPPs for the benefit of the public at large.

\section{References}

1- SHAH N.M. and MUNDURA S.H.: Clinical profile of organ phosphorous poisoning in a tertiary care centre. Int. J. Med. Sci. Public Health, 5 (8): 1621-5, 2016.

2- SHAH U.K., JAIN H.K., SINGH A. and JATAV O.P.: Clinical profile of organophosphate compound poisoning in a tertiary care centre. Int. J. Multidisciplinary Res. Develop., 2 (3): 40-3, 2015.

3- FLEMING L.E., GOMEZ-MARIN O., ZHENG D., MA F. and LEE D.: National Health Interview Survey mortality among US farmers and pesticide applicators. Am. J. Ind. Med., 43: 227-33, 2003.

4- LONDON L., FLISHER A.J., WESSELING C., MERGLER D. and KROMHOUT H.: Suicide and exposure to organophosphate insecticides; cause or effect? Am. J. Ind. Med., 47 (4): 308-21, 2005.

5- ADINEW, et al.: Pattern of acute organophosphorus poisoning at Getnet Mequanint Adinew*, Assefa Belay Asrie and Eshetie Melese Birru BMC Res Notes, 10: 149 DOI 10.1186/ s13104-017-2464-5, 2017.

6- CHATAUT J., ADHIKARI N.P. and SINHA S.B.: Pattern of organ phosphorous poisoning; a retrospective community based study. Kathmandu Uni Med J., 9 (34): 31-4, 2011. 
7- BANERJEE I., TRIPATHI S.K. and ROY A.S.: Clinicoepidemiological characteristics of patients presenting with organ phosphorus poisoning. North Am. J. Med. Sci., 4 (3): 147-50, 2012.

8- AMIN D.M., ABAZA M.T., EL AZAWY D.S. and AHMED A.I.: Morbidity and Mortality Indicators in Acute Organophosphate Poisoning in Zagazig University Hospital, Egypt: Retrospective Study, Occupational Diseases and Environmental Medicine, 6: 130-140, 2018.

9- SELVARAJ T. and SUDHARSON T.: Demographic and Clinical Profile of Organ phosphorus Poisoning cases in a Medical College Hospital, Tamil Nadu* Indian Journal of Forensic and Community Medicine April-June, 3 (2): 124-127, 2016.

10- KHAN S., KUMAR S., AGRAWAL S. and BAWANKULE S.: Correlation of serum cholinesterase and serum creatine phosphokinase enzymes with the severity and outcome of acute organ phosphorus poisoning-study in rural central India. World J. Pharmacy Pharmac Sci., 5 (4): 1365-1373, 2016.

11- Ojha U.K., et al.: Profile of organo phosphorous poisoning at a tertiary medical centre in Jharkhand, India. International Journal of Advances in Medicine, NovemberDecember 2018 | Vol 5 | Issue 6 Int. J. Adv. Med., Dec. 5 (6): 1510-1514, 2018.

12- CHINTALE K.N., PATNE S.V. and CHAVAN S.S.: Clinical profile of organophosphorus poisoning patients at rural tertiary health care centre. Int. J. Adv. Med., 3 (2): $268-274,2016$
13- MOHAMMED A. AL JUMAAN, MOHAMMAD S. AL SHAHRANI, MOHEY H. AL WAHHAS and AMAL H. AL SULAIBEAKH: Organophosphate Poisoning: A 10 Year Experience at a Tertiary Care Hospital in the Kingdom of Saudi Arabia Department of Emergency Medicine, King Fahd Hospital of the University, University of Dammam, Dammam, Kingdom of Saudi Arabia, Saudi Journal of Medicine \& Medical Sciences | Vol. 3 | Issue 1 | January 2015.

14- NOSHAD H., ANSARIN K., ARDALAN M.R., GHAFFARI A.R., SAFA J. and NEZAMI N.: Respiratory failure in organophosphate insecticide poisoning. Saudi Med. J., 28 (3): 405-407, 2007.

15- DIVEKAR S., et al.: Clinical profile of patients presenting with inhalational organ phosphorus poisoning in central India: A retrospective study. Int. J. Community Med. Public Health, Aug. 7 (8): 3047-3051, 2020.

16- RAO G.V. and JYOTHSNA M.: Relation between Serum Cholinesterase and Mortality among Patients with OP Poisoning. Indian J. Clin. Anaesth., 3 (1): 48-51, 2016.

17- GAGARIN P. and RAJAGOPAL R.: Clinical profile and outcome of organ phosphorus poisoning in a tertiary care centre, a prospective observational study International Journal of Medical Research and Review, Volume 8 Number 2 March-April, 2020.

18- SHAH S.M., ASARI P.D. and AMIN A.J.: Clinicoepidemiological profile of patients presenting with acute poisoning. Int. J. Curr. Res. Rev., 8 (13): 35-41, 2016.

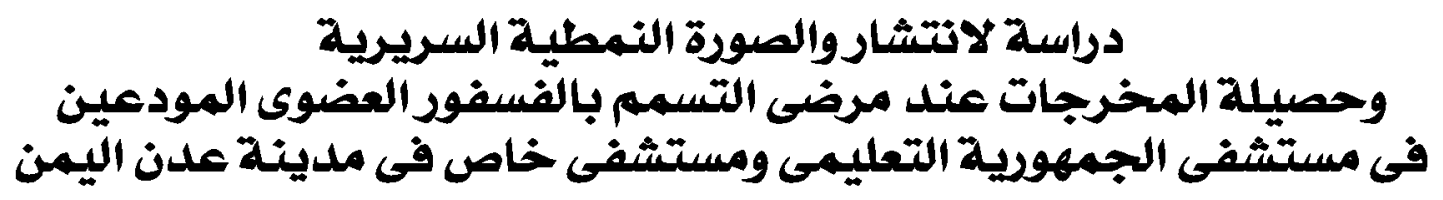

الاقتصاد. المقدمة: مر كبات الفوسفات العضوية تعتبر الاكثر شيوعاً للتسمم في الدول النامية بما فيها اليمن حيث الزراعة عنصر أساسي في

الأهداف:تهدف الدراسة لوصف الانتشار والصورة النمطية السريرية وحصيلة المخرجات لمرضى التسمم بالفوبفات العضوية المودعين في مستشفى الجمهوية التعليمى ومستشفى خاص في مدينة عدن اليمن.

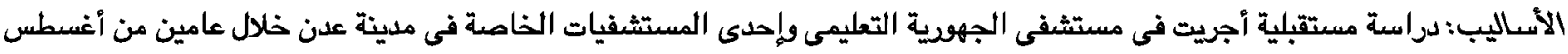

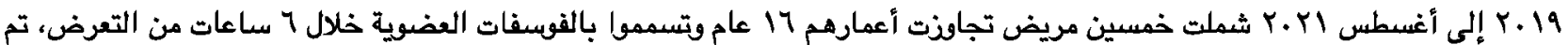

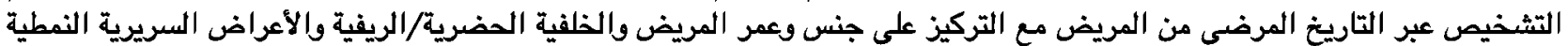

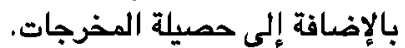

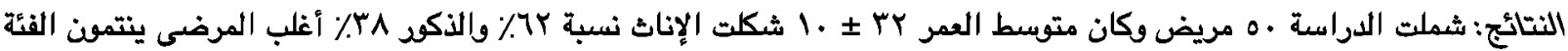

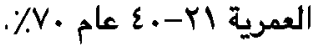

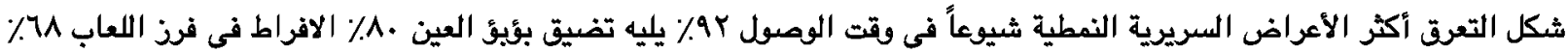

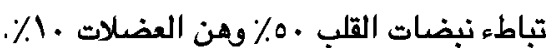

عدد المرضي الذين توفوا YY\% بينما الذين تعافوا بشكل كامل ع ٪\% الخلاصة: خلصت الدراسة إلى أن الأناث هـ أغلبية المرضى والتعرق كان أكثر الأعراض شيوعاً. 